\title{
Legal Protection for Justice Collaborator in Revealing Criminal Act Cases in Courts
}

\author{
Lufti Nurmansyah ${ }^{1}$ \\ \{luftinurmansyah@gmail.com\} \\ ${ }^{1}$ Department of Law, Universitas Jayabaya, Indonesia
}

\begin{abstract}
Justice collaborators play a paramount role in dismantling and eradicating crimes. There are several existing forms of legal protection provided to justice collaborators such as the reduction of the prison term given by the Panel of Judges, and special protection against threats or intimidation directed at him or his family. This study was aimed to investigate the forms of legal protection for justice collaborators, requirements for a perpetrator to be categorized as a justice collaborator and benefits for the perpetrator if he is willing to be a justice collaborator. The research method used is descriptive analysis method, the systematic exposure of a fact or reality through a normative juridical approach. The results showed that the legal protection for a justice collaborators are imposing special conditional probation penalties and imposing the lightest prison sentence of any other defendants who are proven guilty in the case. The requirements for a perpetrator to become a justice collaborator are (1) be one of the perpetrators of a certain criminal acts, but not the main perpetrator (2) willing to provide comprehensive information in the judicial process.
\end{abstract}

Keywords: Justice Collaborator, Legal Protection

\section{Introduction}

Criminal Justice System is defined as a system in a community to tackling crime. Tackling is defined as controlling crime so that it is within the limits of tolerance. Regarding to Criminal Procedure Code as a whole, it can be seen that the rights of the suspect / defendant are highly prioritized, while the rights of witnesses and victims are ignored. According to Marjono Reksodiputro the Criminal Justice System is considered to have paid too much attention to the problem and the role of the perpetrators of crime (offender-centered) [1].

The role of witnesses in every criminal trial is very important because often witnesses' information can influence and determine the tendency of judges' decisions. A witness is considered to have the ability to determine the direction of the judge's decision. This gives an effect in each witness's testimony always receives great attention both by legal actors involved in the trial and the public observers of the law [2].

In the KUHAP (Criminal Procedure Code) the position of a witness is one of the legal evidences according to the provisions of article 184 of the Criminal Procedure Code, and according to the provisions of article 1 of the Criminal Procedure Code, a witness is a person who can provide information for the purposes of investigation, prosecution and trial of a particular criminal case which he heard himself, he saw for himself and he experienced himself [3]. 
Based on the Supreme Court Circular Letter No. 04 of 2011 (SEMA 4/2011), Justice collaborator is interpreted as a particular criminal offender, but not the main perpetrator, who acknowledges his actions and is willing to be a witness in the judicial process. In addition to the justice collaborator in the SEMA, it also regulates whistleblowers, the ones who know certain criminal acts then report the case and are not one of the prepertrators of the action.

The role of witnesses in every criminal trial in court is very important because often witness statements can influence and determine the tendency of judges' decisions. The witness becomes one of the judges determining whether a person is guilty or not. This certainly has an effect on each witness's testimony always receiving great attention both by law enforcers involved in the trial as well as the general public. Therefore, the witness should be given legal protection because in revealing a criminal act the witness consciously takes the risk in revealing material truth.

In the General Provisions of Article 1 of Law No. 13 of 2006 concerning Protection of Witnesses and Victims, it is stated that LPSK is an institution which is in charge to provide rights and protection to victims and / or witnesses. Observing the characteristics of the tasks and authorities carried by LPSK, LPSK is an institution in the scope of the criminal justice system, particularly in the investigation, prosecution and trial stages [4]. However, the practice in each institution, especially law enforcement agencies both the KPK, the Police, and the Prosecutors' Office in implementing this regulation have various versions. It's quite strange to have different implementation in the same court, same government with the same rules. Besides, the determination of justice collaborator is not yet clear and there are still different perceptions of each law enforcement especially in treating a Justice Collaborator [5].

For instance, several major cases were revealed with a valuable information from justice collaborators, but what happened was that justice collaborators actually received criminal penalties. One of them is Agus Condro. The Corruption Court, on Thursday, June 16, 2011 sentenced him to 15 months in prison and a fine of Rp 50 million. Agus Condro, as the Reporter for the bribery case, the traveler checks for the election of the Deputy Governor of BI, the sentence is not much different from the other defendants in the same case. This ruling is very contradictory to LPSK's recommendation, the Panel of Judges should consider Agus Condro's position as a person who contributes and cooperates with law enforcement officials to uncover corruption cases. As the first person to reveal the bribery case of the election of Agus Condro who was the Senior Deputy Governor of Bank Indonesia should have obtained his rights as stipulated in Law No. 13 of 2011 concerning Protection of Witnesses and Victims [6].

Determination should be an important note of the uncertainty of what is meant by the right of justice collaborators to get "legal protection". Then in special handling, the delay in the legal process will be carried out in the period of time, for prisoners who have the status as justice collaborator will get additional remissions and other prisoners' rights, but it is not explained what those rights are like. Besides, there still some difficulties in determining the main actors and not the main actors.

Based on the background that has been described, the researcher was haunted to investigate the Legal Protection for Acting Witnesses (Justice Collaborator) in Exposing Criminal Cases in Courts).

The formulation in this research is (1) how the forms of legal protection for Justice Collaborator and (2) what are the conditions for a criminal offender can be categorized as Justice Collaborator, and what benefits are obtained by perpetrators who are willing to become Justice Collaborators. 


\section{Method}

The purpose of this study was to investigate the forms of legal protection for justice collaborators, the requirements for a perpetrator to become a justice collaborator and benefits for the perpetrator if he is willing to be a justice collaborator.

The research method used in this study is descriptive analysis method; the systematic exposure of a fact or reality through a normative juridical approach and qualitative analysis. Normative legal approach method, legal research conducted by examining library materials or secondary data is used to support the investigation. Normative legal research is also called doctrinal law research due to the fact that this research is conducted only at written regulations or other legal materials [7]. Supporting secondary data is done by looking at the facts that occur in the Justice Collaborator.

\section{Result and Discussion}

\subsection{Forms of Legal Protection for Justice Collaborators}

In Indonesia, non-victim witnesses have been developed in proving organized crime cases, that is what is called as a collaborating witness or justice collaborator. Judging from the terminological perspective, justice collaborator is defined as a "whistleblower" witnesses who collaborate "," pentiti "I" pentito "I" callaboratore della giustizia ". In the latest developments, the Supreme Court through the Supreme Court Circular Letter Number: 04 of 2011 regarding the treatment of whistleblowers and justice collaborators is one of the perpetrators of certain criminal acts, admitting the crime committed, not the perpetrator major in the crime and provide information as a witness in the trial process [8].

The development of the idea of justice collaborator starts from the provisions of Article 37 paragraph (2) of the 2003 United Nations Convention Against Corruption (UNCAC) which has been ratified by Indonesia through Law Number 7 of 2006 concerning ratification of the convention in 2003. Then in Article 37 paragraph (3) the UNCAC. Furthermore, in a joint decree between the witness and victim protection agency (LPSK), the Attorney General's Office, the Indonesian Police, the KPK, and the Supreme Court. Justice collaborator is a witness, who is also a perpetrator, but wants to cooperate with law enforcement in order to dismantle a case and even return the assets resulting from corruption if the asset is in him [9].

In the provisions of positive Indonesian law, justice collaborators are briefly regulated in Law Number 13 of 2006 in conjunction with Law Number 31 of 2014 concerning Amendments to Law Number 13 of 2006 (Regarding Witness and Victim Protection), United Nation Convention Against Corruption ( UNCAC), Law Number 31 of 1999 jo Law Number 20 of 2001, Joint Regulations on the Law and Human Rights of the Republic of Indonesia, Attorney General of the Republic of Indonesia, Chief of the Indonesian National Police, Corruption Eradication Commission of the Republic of Indonesia, Chair of the Protection Agency Witnesses and Victims of the Republic of Indonesia Number: M.HH-11.HM..03.02.Th. 2011 Number: PER-045 / A / JA / 12/2011, Number: 1 of 2011, Number: KEPB-02 / 01-55 / 12/2011, Number: 4 of 2011 concerning Protection for Reporters, Reporting Witnesses and Acting Witnesses in Collaboration, Indonesian Supreme Court Circular Letter number: 04 of 2011 Concerning Treatment for Reporters of Criminal Acts (whistle blowers) and Witness Actors who Cooperate (justice collaborator) in Certain Criminal Cases [10].

This Joint Regulation cannot run optimally due to the lack of understanding from law enforcers, especially in the regions due to lack of socialization, the constraints on the legal structure are related to the LPSK institution. First, the position of LPSK is independent but must run a program that must be supported by law enforcement agencies, especially in the case of protection of justice collaborators in 
the form of special handling. In practice, sometimes it happens because of the independence of this LPSK. LPSK is sometimes considered to intervene in the authority of officials of law enforcement and the problems of the regional LPSK. Second, related tasks and authorities related to the cooperation of related agencies in practice is difficult to apply. Third, the structure and infrastructure of LPSK.

In this joint regulation agreed conditions for obtaining protection for justice collaborators. The protections provided are: First, the remission of penalties, including prosecution; second, the granting of additional remission and other inmate rights is in accordance with the prevailing legislation when the Cooperating Witness is a convict. As stated in the Supreme Court Circular No. 4 of 2011 on the treatment for Reporting Crime and Witnesses actors who Work In Case Specific Crime has provided legal protection for Justice Collaborator is dropping criminal trial conditional specifically for Justice Collaborator, convict the form of imprisonment at least among the other defendants who were found guilty on the matter.

\subsection{Conditions for a Criminal Actor Who Can Be Categorized as a Justice Collaborator and the Benefits Obtained by Actors Who Willing to Become a Justice Collaborator}

The definition of justice collaborator according to the Supreme Court Circular Number 4 of 2011 is someone who is one of the perpetrators of a crime, recognizes the crime he committed, is not the main perpetrator in the crime, and provides information as a witness in a very significant court process so that it can reveal the criminal offense is effectively referred to, revealing other actors who have a greater role and returning the assets / proceeds of a crime.

Justice collaborator is a collaborating agent, a person who is a witness, reporter or informant who provides assistance to law enforcers, for example in the form of providing important information, strong evidence or testimony / under oath, which can reveal a criminal act, in where the person is involved in the reported crime or even another crime [11]. The term justice collaborator can also be referred to as a whistleblower or who wants to work with law enforcement or whistle-blower participants. The whistleblower must be someone in the organization who can be involved or not involved in the reported crime [12].

In Law Number 31 of 2014 concerning Protection of Witnesses and Victims Article 1 number 2, what is meant by witnesses, perpetrators or other terms of justice collaborator, stated that the perpetrators' witnesses are suspects, defendants, or convicts who work closely with law enforcement to uncover a criminal act in a case same. Of course, it is not an easy matter to become a whistleblower and justice collaborator because it is not without risk for someone to take the courageous choice to blow his whistle, hit the block, and divulge the secret to expose the crime. As an insider becoming part of the environment where the information he is leaking, is certainly very understanding about what and how the mode of crime that has been neatly wrapped and is confidential to the public and law enforcement agencies.

Considering the risk and responsibility to become a whistleblower and justice collaborator, therefore Law 31 of 2014 gives a kind of appreciation to those who want to become whistleblowers and justice collaborators as a form of participation in tackling crimes that are extraordinary crimes. Article 10 of Law Number 31 Year 2014 provides protection for both. As regulated in article 10 are as follows: Article 10 (1) Witnesses, victims, witnesses, perpetrators, and / or reporters cannot be prosecuted, both civil and criminal, for testimonies and / or reports that will, are, or he has given, unless the testimony or report is given in good intention.

In the article 10 (2), in the event that there are lawsuits against witnesses, victims, perpetrators, and / or reporters on testimonies and / or reports that will be, are being, or have gained, these lawsuits 
should be delayed until the reported case or that had been established by a court and obtained permanent legal force.

Regulations relating to the Justice Collaborator are regulated in Point 9 regarding guidelines / conditions for determining someone as a witness to the collaborating actor (Justice collaborator) as follows:

1) The person concerned is one of the perpetrators of certain criminal acts as referred to in this SEMA, acknowledging the crime committed, not the main perpetrator in the crime and providing information as a witness in the trial process.

2) The public prosecutor in his claim states that the person concerned has very significant information and evidence so that the investigator and / or public prosecutor can effectively disclose the said criminal act, disclose other actors who have a greater role and / or return assets / proceeds of a crime.

3) For the assistance, the witness who cooperates as referred above, the judge can determine the criminal to be imposed and consider matters of criminal offense as follow; (1) impose special conditional probation penalties, (2) imprisonment in the form of the lightest imprisonment of the defendants among those who convicted in the case.

The arrangements relating to the Justice Collaborator are regulated in Article 1 as follows: Point (3) Witnesses in Collaborating Actions are witnesses who are also perpetrators of a criminal offense who are willing to assist law enforcement officials to uncover a criminal act or a criminal act to return assets or proceeds of a criminal offense to the state by providing information to law enforcement officials and giving testimony in the judicial process.

Meanwhile, the benefit gained from the Justice Collaborator is that no criminal or civil claim may be prosecuted for the testimony or report provided. However, does the provisions stipulated in this article guarantee that a Justice Collaborator will not be prosecuted, expressly contained in the Supreme Court Circular Letter Number 4 year 2011 about Treatment for Reporters of Criminal Actions and Witnesses of Actors Collaborating in Certain Crimes Cases have provided legal protection for Justice Collaborator, namely imposing a conditional trial sentence specifically for Justice Collaborator, imposing a criminal sentence in the form of the lightest imprisonment among other defendants who were proven guilty in the case in question.

To strengthen the role of the Justice Collaborator with regard to eradicate corruption, the role of law enforcement in criminal justice process is very important. Beginning with the investigation, prosecution and trial hearings the court must consider the rights of the Justice Collaborator as a witness. The large number of law enforcers who always follow up on reports of defamation by people revealed by the Justice Collaborator greatly disturb the psychological condition of the Justice Collaborators. With the disruption of the psychological condition of the Justice Collaborators influences the eradication of criminal acts. Many Justice Collaborators are disappointed with the existing law enforcement process. Good intentions want to expose cases that are high-class, they must be sued back only by article 310 of the Criminal Code about defamation. With the effort and enthusiasm to handle criminal crime in Indonesia, including improvement of the system within the scope of the court, we should not ignore the role of a Justice Collaborator. The role of the Justice Collaborator in the criminal role system is very important, because criminal law enforcement is not sufficient with the structure of law enforcement agencies 


\section{Conclusion}

Justice collaborators have been legally protected. SEMA has provided legal protection for Justice Collaborators, namely imposing special conditional probation penalties for Justice Collaborators, imposing the lightest criminal sentences among the defendants the other is proven guilty in the case in question. The requirement to become a Justice Collaborator is first, the person concerned is one of the perpetrators of a particular crime. as referred to in SEMA, recognizes the crime committed, not the main perpetrator in the crime and provides information as a witness in the judicial process. Second, the Public Prosecutor in his claim stated that the person concerned had information and evidence that was very significant so that the investigator and / or public prosecutor could effectively disclose the criminal act, disclose other actors who had a greater role and / or restore assets / proceeds of a crime. Third, for this assistance, the judge is benefited in considering and determining the criminal sanction to be imposed.

\section{Acknowledgments}

The Author wishes to thank the Head of Semarang State University and Head of Faculty of Law for providing a facility to join International Conference in ICILS $3^{\text {rd }}$ International Conference 2020.

\section{References}

[1] Many witnesses and victims of crime were found to lack adequate legal protection. Witnesses and victims of crime are placed as evidence that provides information in this case as witnesses so that the possibility for victims to gain freedom in fighting for their rights is low. Mardjono Reksodiputro, Hak Asasi Manusia Dalam Sistem Peradilan Pidana: Kumpulan Karangan Buku Ketiga: Third Book Essay Collection, Center for Justice and Legal Services University of Indonesia, Jakarta, 1994, pp. 84-85.

[2] Muhadar et al, Perlindungan Saksi Dan Korban Dalam Sistem Peradilan Pidana, CV. Putra Media Nusantara, Surabaya, 2009, p.1.

[3] In a criminal offense, in a trial of a criminal case the evidencing law is very important in proving guilt in a court hearing. Without witnesses, a crime will be difficult to reveal the truth. Witness testimony is a trial evidence which is one of the judges' basic considerations to determine whether a defendant has proven his conduct or not. Criminal Procedure Code Article 1 of the Criminal Procedure Code.

[4] Lies Sulistiani, Pentingnya Lembaga Perlindungan Saksi dan Korban dalam Upaya Penegakan Hukum dan HAM di Indonesia, buletin Kesaksian LPSK March-April 2009, pg 11.

[5] Muhadar, et al. Perlindungan Saksi dan Korban Dalam Sistem Peradilan Pidana, Putra Media Nusantara, Surabaya, 2009, pg. 23

[6] www. Elsam.or.id, A.H.Semendawai, SH, LL.M, Head of LPSK RI, Penanganan dan Perlindungan,,Justice Collaborator"Dalam Sistem Hukum Pidana diIndonesia, retrieved on 2 March 2020, pg. 8

[7] Soerjono Soekanto, and Sri Mamudji, Penelitian Hukum Normatif Suatu Tinjauan Singkat, PT Raja Grafindo Persada , Jakarta, 2003, pg.13

[8] According to Ilias Chtzis and the UND Team, witness protection first appeared in the United States in the 1970s as a legal procedure that could be used in conjunction with a program to dismantle a mafia type crime organization. Until then, the "silent oath" - known as an unwritten 
omertà among Mafia members, cannot be shaken, threatening the lives of anyone who violates and cooperates with the police. Important witnesses cannot be persuaded to testify and the key witnesses disappear due to the efforts of the leaders of the crime groups who are the target of the prosecution. This initial experience convinced the United States Law Department that a witness protection program needed to be instituted. Lilik Mulyadi, Perlindungan Hukum Terhadap Whistleblower Dan Justice Collaborator Dalam Upaya Penanggulangan Organize Crime, P.T. Alumni, Bandung, 2015, page 5

[9] Firman Wijaya, Whistleblower Dan Justice Collaborator Dalam Persfektif Hukum, Penaku, Jakarta, 2012, pg.7.

[10] Lilik Mulyadi, Perlindungan Hukum Terhadap Whistleblower Dan Justice Collaborator Dalam Upaya Penanggulangan Organize Crime, P.T. Alumni, Bandung, 2015, pg. 11

[11] Legal Mafia Eradication Task Force, Perlindungan Terhadap Pelaku Yang Bekerjasama (Justice Collaborator): Usulan Dalam Rangka Revisi UU Perlindungan Saksi dan Korban, Legal Mafia Eradication Task Force, Jakarta, 2011, pg 3

[12] Firman Wijaya, Whistleblower Dan Justice Collaborator Dalam Persfektif Hukum, Penaku, Jakarta, 2012, pg. 11 